\title{
Prohexadione-Ca: A Promising Chemical for Controlling Vegetative Growth of Apples
}

\author{
C.R. Unrath \\ Department of Horticultural Science, North Carolina State University, Mountain Horticultural Crops Research \\ and Extension Center, 2016 Fanning Bridge Road, Fletcher, NC 28732-2016
}

Managing growth of apple (Malus $\times$ domestica Borkh.) trees is an ongoing concern for orchardists. Reducing growth of young trees to hasten flowering and fruiting, containment of bearing trees to their allocated space to prevent crowding and excessive shading, and controlling vegetative growth in crop loss years are all challenges to apple growers. Historically, the most successful commercial strategy for controlling vegetative growth has been the use of $\mathrm{Alar}^{\otimes}$ (daminozide; 2,2 dimethylhydrazide) alone or tank-mixed with ethephon (2chloroethyl phosphonic acid). With the withdrawal of the Alar label, effective vegetative growth control options for apples were essentially eliminated.

A new class of growth retardants, the acylcyclohexanediones, are now available (Rademacher et al., 1992). Their mode of action is the inhibition of either $2 \beta$-hydroxylase (Griggs et al., 1991) or $3 \beta$ hydroxylase (Nakayama et al., 1992), which blocks gibberellin synthesis. One of these chemicals, prohexadione-Ca (BAS-125, or Apogee $^{\circledR}$ ) is being extensively researched. Nakayama et al. (1990) reported that prohexadione-Ca (PHD-Ca) retarded shoot elongation in rice, and that the reduction in elongation was directly related to inhibition of gibberellin biosynthesis (Nakayama et al., 1992). This compound is currently being evaluated for its effects on many different crops. This research reports on the response of apples to PHD-Ca under orchard conditions.

\section{MATERIALS AND METHODS}

The growth regulator was applied with a three-point hitch airblast sprayer with a 32 -inch $(81.3 \mathrm{~cm})$ variable pitch fan, or hand gun treatments were applied to runoff using the same sprayer from the hose bib attachment. All airblast applications were based on tree row volume (TRV) calculated dilute water requirement for pesticide application (Sutton and Unrath, 1988). All PHD-Ca solutions included $0.1 \%$ (v/v) Regulaid ${ }^{\circledR}$ (Kalo, Overland Park, Kans.) as a surfactant. Control trees were not sprayed.

A list of experiments conducted, location and description of the trees used, and the experimental designs utilized are shown in Table 1.

All data were statistically analyzed by analysis of variance and mean separation tested by Duncan-Waller LSD (SAS Institute, Cary, N.C.).

Received for publication 14 July 1998. Accepted for publication 20 Aug. 1998. Use of trade name does not constitute endorsement by the North Carolina Agricultural Research Service of the products named and does not imply criticism of similar ones not mentioned. The cost of publishing this paper was defrayed in part by the payment of page charges. Under postal regulations, this paper therefore must be hereby marked advertisement solely to indicate this fact.
Expt. 1. Concentrations of 0, 125, 250, and $375 \mathrm{mg} \cdot \mathrm{L}^{-1} \mathrm{PHD}-\mathrm{Ca}$ were applied 7 days after petal fall (DAPF). The $250 \mathrm{mg} \cdot \mathrm{L}^{-1}$ rate was also applied 0, 14, and 21 DAPF.

Expt. 2. After dormant pruning the previous winter, trees were measured and water volume for PHD-Ca spray applications was based upon TRV. Single PHD-Ca applications of $0,125,250$, or $500 \mathrm{mg} \cdot \mathrm{L}^{-1}$ were applied at $21 \mathrm{DAPF}$. In addition, the $125-\mathrm{mg} \cdot \mathrm{L}^{-1}$ treatment was applied at both 21 and $51 \mathrm{DAPF}$. The TRV was monitored to determine the effectiveness of PHD-Ca in controlling shoot elongation and in overall tree size throughout the remainder of the growing season.

Expt. 3. Eight PHD-Ca treatments were applied between petal fall (PF) and $30 \mathrm{DAPF}$, either as single or multiple applications totaling either 250 or $500 \mathrm{mg} \cdot \mathrm{L}^{-1}$ (Table 6).

Expt. 4. The orchard used in 1996 was again used in 1997. Lower rates $\left(0,31,62\right.$, and $\left.94 \mathrm{mg} \cdot \mathrm{L}^{-1}\right)$ of PHD-Ca were applied beginning at PF. Each concentration was applied one, two, three, or four times at 10$\mathrm{d}$ intervals. An additional $125 \mathrm{mg} \cdot \mathrm{L}^{-1}$ was applied to treatments that showed renewed terminal budbreak and shoot extension at 60 DAPF (see Table 7). Also, treatments 4, 5, and 6 from Expt. 3 (Table 6) were retreated with the same treatments and their response was compared with trees treated for the first time in 1997.

Expt. 5. Response to PHD-Ca of an orchard at a low-elevation orchard (275 m) in Laurens County, S.C., was compared with that of a similar orchard (Expt. 4) in North Carolina at a higher elevation (700 $\mathrm{m})$. Average temperatures were higher and tree vigor greater at the South Carolina site. In South Carolina, concentrations of 0, 40, 60, 80, and $100 \mathrm{mg} \cdot \mathrm{L}^{-1}$ were applied as four sequential sprays, beginning at $\mathrm{PF}$; additionally, a 40-mg. $\mathrm{L}^{-1}$ treatment applied at PF, 10 and $20 \mathrm{DAPF}$ was followed at $30 \mathrm{DAPF}$ with a $120-\mathrm{mg} \cdot \mathrm{L}^{-1}$ application. The randomized complete-block design with two trees per plot was split, and one tree per plot received an additional $125 \mathrm{mg} \cdot \mathrm{L}^{-1}$ at $60 \mathrm{DAPF}$.

Expt. 6. These trees were nonbearing due to a frost/freeze crop loss in 1997. The response to PHD-Ca at $200 \mathrm{mg} \cdot \mathrm{L}^{-1}$ was compared with that to a tank mix of daminozide at $1500 \mathrm{mg} \cdot \mathrm{L}^{-1}$ plus ethephon at 600 $\mathrm{mg} \cdot \mathrm{L}^{-1}$.

\section{RESULTS}

Expt. 1. Handgun treatments in 1994 significantly reduced shoot growth (SG), but response did not differ with concentration used (Table 2). These results are similar to those reported by Green (1996). The time of application did not affect subsequent S.G. response (Table 2). Fruit set was increased by treatment at 0,7 , or 14 DAPF (Table 3 ). The inhibition of growth greatly reduced the amount of pruning required, measured either as number of cuts or weight of prunings (Table 3). The most graphic illustration of the influence of PHD-Ca on

Table 1. Experiments conducted with PHD-Ca (1994-97).

\begin{tabular}{|c|c|c|c|c|c|c|c|c|}
\hline $\begin{array}{l}\text { Expt. } \\
\text { no. }\end{array}$ & Year & $\begin{array}{l}\text { Strain and } \\
\text { cultivar }\end{array}$ & Rootstock & $\begin{array}{c}\text { Tree age } \\
\text { (years) }\end{array}$ & $\begin{array}{c}\text { Method } \\
\text { of application }\end{array}$ & $\begin{array}{c}\text { Date } \\
\text { of petal fall }\end{array}$ & $\begin{array}{c}\text { Expt. } \\
\text { design }\end{array}$ & $\begin{array}{c}\text { No. replications } \\
\text { (trees) }\end{array}$ \\
\hline 3 & 1996 & Granny Smith & M.7 & 11 & Airblast & 1 May & RCB & 6 \\
\hline 4 & 1997 & Granny Smith & M.7 & 12 & Airblast & 15 Apr. & $\mathrm{RCB}$ & 6 \\
\hline $5^{y}$ & 1997 & Granny Smith & M.7 & 13 & Airblast & 5 Apr. & $\begin{array}{c}\text { RCB/ } \\
\text { split plot }\end{array}$ & 4 \\
\hline
\end{tabular}

${ }^{2} \mathrm{RCB}=$ randomized complete block.

${ }^{y}$ Conducted in Laurens County, S.C. All others conducted in Henderson County, N.C. 
Table 2. The effect of PHD-Ca treatments (time of application and concentration) on shoot length (cm) of 'Delicious' apple trees (Expt. 1, 1994).

\begin{tabular}{lcccc}
\hline \hline Treatment & \multicolumn{4}{c}{ Time of application (DAPF) } \\
\cline { 2 - 5 } concn $\left(\mathrm{mg} \cdot \mathrm{L}^{-1}\right)$ & 0 & 7 & 14 & 20 \\
\hline 0 & $40 \mathrm{a}^{\mathrm{y}}$ & --- & --- & --- \\
125 & --- & $21 \mathrm{~b}$ & --- & -- \\
250 & $13 \mathrm{~b}$ & $23 \mathrm{~b}$ & $21 \mathrm{~b}$ & $19 \mathrm{~b}$ \\
375 & --- & $18 \mathrm{~b}$ & --- & --- \\
\hline
\end{tabular}

${ }^{2}$ DAPF $=$ days after petal fall.

${ }^{y}$ Mean separation among all treatments by Duncan-Waller LSD, $P \leq 0.05$.

tree growth is shown in the shift in distribution of shoot length (Table 3 ). The treatments dramatically increased the percentage of shorter shoots $(0-10$ and $10-25 \mathrm{~cm})$. The unusually high percentage in the shortest group for $250 \mathrm{mg} \cdot \mathrm{L}^{-1}$ at $\mathrm{PF}$ is probably an artifact of greater tissue sensitivity in the early treatment, which resulted in loss of apical dominance and growth of laterals (data not shown). This situation was not observed with other treatments or in any subsequent airblast tests.

Expt. 2. Treatments had similar effects in 1995 (SG data not shown). To illustrate the overall influence on the total tree, and the related impact on later season pesticide water application rates, data are presented as differences in TRV calculated water rates required for dilute pesticide applications (Table 4). Application of a total of 250 $\mathrm{mg} \cdot \mathrm{L}^{-1}$ (treatments 3,4 , and 5) reduced water requirements $20 \%$ to $25 \%$ and reduced TRV more than did the 500- and $125-\mathrm{mg} \cdot \mathrm{L}^{-1}$ treatments. The best response was obtained with two applications of $125 \mathrm{mg} \cdot \mathrm{L}^{-1}$ (treatment 3 ).

Expt. 3. In 1996, a single application of $250 \mathrm{mg} \cdot \mathrm{L}^{-1}$ applied at either 7 or $21 \mathrm{DAPF}$ was just as effective as $500 \mathrm{mg} \cdot \mathrm{L}^{-1}$ applied $21 \mathrm{DAPF}$ (Table 5). However, the treatment at 7 DAPF was more effective because it was applied when less growth had occurred. When PHD-Ca was applied at 62 and $188 \mathrm{mg} \cdot \mathrm{L}^{-1}$ at 14 and $21 \mathrm{DAPF}$, respectively, a third application of $250 \mathrm{mg} \cdot \mathrm{L}^{-1}$ at $30 \mathrm{DAPF}$, which doubled the total amount of PHD-Ca applied, had no additional effect on shoot growth (Table 5). Treatments 4, 5, and 6, all of which received a total of 250 $\mathrm{mg} \cdot \mathrm{L}^{-1}$ of PHD-Ca, differed only by the amount of extension that occurred before treatment.

Expt. 4. In 1997, regardless of the concentration used, numbers of applications or total concentration applied, all PHD-Ca treatments significantly reduced shoot length (Table 6). Trees receiving a single application of 31 , single or double applications of $62 \mathrm{mg} \cdot \mathrm{L}^{-1}$, or a single application of $94 \mathrm{mg} \cdot \mathrm{L}^{-1}$ all showed regrowth by $60 \mathrm{DAPF}$ and were retreated at time with $125 \mathrm{mg} \cdot \mathrm{L}^{-1}$. Three or four sequential applications of 31,62 , or $94 \mathrm{mg} \cdot \mathrm{L}^{-1}$, none of which permitted regrowth at $60 \mathrm{DAPF}$, were all equally effective (treatments 2 and 3, 6 and 7, 10 and 11).

When trees that received effective treatments in 1996 (Table 5,

Table 3. The effect of time of application of PHD-Ca $\left(250 \mathrm{mg} \cdot \mathrm{L}^{-1}\right)$ on fruit set, on pruning, and on percentage of shoots by length of 'Delicious' apple trees (Expt. 1, 1994).

\begin{tabular}{|c|c|c|c|c|c|c|c|}
\hline \multirow{2}{*}{$\begin{array}{l}\text { Time of application } \\
(\mathrm{DAPF})^{\mathrm{y}}\end{array}$} & \multirow{2}{*}{$\begin{array}{c}\text { Fruit set } \\
\text { (no./cm limb circ.) }\end{array}$} & \multirow{2}{*}{$\begin{array}{l}\text { No. pruning } \\
\text { cuts/tree }\end{array}$} & \multirow{2}{*}{$\begin{array}{l}\text { Pruning wt } \\
(\mathrm{g})\end{array}$} & \multicolumn{4}{|c|}{ Percentage of shoots by length ${ }^{\mathrm{x}}(\mathrm{cm})$} \\
\hline & & & & $>10$ & $10-25$ & $25-40$ & $40+$ \\
\hline Control & $4.1 \mathrm{a}^{\mathrm{x}}$ & $111 \mathrm{a}$ & $1538 \mathrm{a}$ & 2 & 23 & 35 & 40 \\
\hline 0 & $6.7 \mathrm{c}$ & $34 \mathrm{~b}$ & $454 \mathrm{~b}$ & 65 & 20 & 10 & 5 \\
\hline 14 & $5.5 \mathrm{bc}$ & $51 \mathrm{~b}$ & $581 \mathrm{~b}$ & 20 & 55 & 10 & 15 \\
\hline 21 & $4.8 \mathrm{ab}$ & $35 \mathrm{~b}$ & $269 \mathrm{~b}$ & 30 & 40 & 20 & 10 \\
\hline
\end{tabular}

${ }^{2}$ No statistical analysis; observational data only.

${ }^{y} \mathrm{DAPF}=$ days after petal fall.

${ }^{x}$ Mean separation with columns by Duncan-Waller LSD, $P \leq 0.05$.

Table 4. The effects of PHD-Ca application on tree growth, expressed as tree row volume (TRV) calculated - dilute pesticide (PD) water application rate, on 'Delicious' apple trees (Expt. 2, 1995).

\begin{tabular}{|c|c|c|c|c|c|c|}
\hline $\begin{array}{l}\text { Treatment } \\
\text { no. }\end{array}$ & $\begin{array}{c}\text { Concn } \\
\left(\mathrm{mg} \cdot \mathrm{L}^{-1}\right)\end{array}$ & $\begin{array}{l}\text { Water application } \\
\text { rate as \% of } \\
\text { initial TRV-PD }\end{array}$ & $\begin{array}{c}\text { No. } \\
\text { applications }\end{array}$ & $\begin{array}{l}\text { Timing of } \\
\text { application } \\
(\mathrm{DAPF})^{\mathrm{z}}\end{array}$ & $\begin{array}{c}\text { End of sason } \\
\text { TRV } \\
\left(\mathrm{L} \cdot \mathrm{ha}^{-1}\right)\end{array}$ & $\begin{array}{l}\text { Reduction in TRV } \\
\text { relative to control } \\
(\%)\end{array}$ \\
\hline$\overline{1}$ & 0 & --- & --- & --- & $4357 \mathrm{a}^{\mathrm{y}}$ & --- \\
\hline 4 & 250 & 100 & 1 & 21 & $3506 \mathrm{~d}$ & 20 \\
\hline 5 & 250 & 50 & 1 & 21 & $3403 \mathrm{~cd}$ & 22 \\
\hline 6 & 500 & 100 & 1 & 21 & $4039 a b$ & 7 \\
\hline
\end{tabular}

${ }^{2} \mathrm{DAPF}=$ days after petal fall.

${ }^{\mathrm{y}}$ Mean separation among all treatments by Duncan-Waller LSD, $P \leq 0.05$

Table 5. The effects of timing, concentration and sequence of applications of PHD-Ca on shoot length of 'Granny Smith' apple trees (Expt. 3, 1996).

\begin{tabular}{|c|c|c|c|c|c|c|c|}
\hline \multirow[b]{2}{*}{ Treatment } & \multicolumn{5}{|c|}{$\begin{array}{l}\text { Concn }\left(\mathrm{mg} \cdot \mathrm{L}^{-1}\right) \text { applied at: } \\
(\mathrm{DAPF})^{\mathrm{z}}\end{array}$} & \multirow[b]{2}{*}{ Total } & \multirow{2}{*}{$\begin{array}{r}\text { Avg shoot } \\
\text { length }(\mathrm{cm}) \\
107 \text { DAPF }\end{array}$} \\
\hline & 0 & 7 & 14 & 21 & 30 & & \\
\hline 1 & 0 & & & & & & $48 a^{y}$ \\
\hline 2 & --- & 250 & --- & --- & --- & 250 & $20 \mathrm{~cd}$ \\
\hline 3 & --- & --- & --- & 250 & --- & 250 & $30 \mathrm{bc}$ \\
\hline 4 & --- & --- & 62 & 188 & --- & 250 & $25 \mathrm{~b}-\mathrm{d}$ \\
\hline 5 & 620 & --- & 62 & 126 & --- & 250 & $18 \mathrm{~d}$ \\
\hline 6 & --- & 62 & --- & 188 & --- & 250 & $22 b-d$ \\
\hline 7 & --- & --- & 62 & 188 & 250 & 500 & $26 b-d$ \\
\hline 8 & --- & --- & --- & 500 & --- & 500 & $31 \mathrm{~b}$ \\
\hline
\end{tabular}

${ }^{2} \mathrm{DAPF}=$ days after petal fall.

${ }^{\mathrm{y}}$ Mean separation among all treatments by Duncan-Waller LSD, $P \leq 0.05$
Table 6. The effects of concentration and number of sequential applications of PHD-Ca on shoot length of 'Granny Smith' apple trees (Expt. 4, 1997).

\begin{tabular}{|c|c|c|c|c|c|c|c|}
\hline \multirow{2}{*}{$\begin{array}{l}\text { Treatment } \\
\text { no. }\end{array}$} & \multicolumn{5}{|c|}{$\begin{array}{l}\text { Concn applied at: } \\
\text { (DAPF) }^{2}\end{array}$} & \multirow[b]{2}{*}{ Total } & \multirow{2}{*}{$\begin{array}{c}\text { Avg shoot } \\
\text { length } \\
(\mathrm{cm})\end{array}$} \\
\hline & 0 & 10 & 20 & 30 & 60 & & \\
\hline 1 & 0 & -- & --- & --- & -- & 0 & $75 a^{y}$ \\
\hline 2 & 31 & 31 & 31 & --- & --- & 93 & $41 \mathrm{~b}$ \\
\hline 3 & 31 & 31 & 31 & 31 & --- & 124 & $31 \mathrm{~b}-\mathrm{d}$ \\
\hline 4 & 31 & --- & --- & --- & 125 & 156 & $29 \mathrm{~b}-\mathrm{d}$ \\
\hline 5 & 62 & 62 & --- & --- & 125 & 187 & $24 \mathrm{~cd}$ \\
\hline 6 & 62 & 62 & 62 & --- & --- & 186 & $38 \mathrm{bc}$ \\
\hline 7 & 62 & 62 & 62 & 62 & --- & 248 & $29 b-d$ \\
\hline 8 & 62 & --- & --- & -- & 125 & 187 & $21 \mathrm{~d}$ \\
\hline 9 & 62 & 62 & --- & --- & 125 & 249 & $23 \mathrm{~d}$ \\
\hline 10 & 94 & 94 & --- & --- & --- & 188 & $34 \mathrm{bc}$ \\
\hline 11 & 94 & 94 & 94 & --- & --- & 282 & $30 \mathrm{~b}-\mathrm{d}$ \\
\hline 12 & 94 & 94 & 94 & 94 & --- & 376 & $39 \mathrm{~b}$ \\
\hline 13 & 94 & -- & -- & --- & 125 & 219 & $32 \mathrm{~b}-\mathrm{d}$ \\
\hline
\end{tabular}

${ }^{2} \mathrm{DAPF}=$ days after petal fall.

${ }^{y}$ Mean separation among all treatments by Duncan-Waller LSD, $P \leq 0.05$. 
Table 7. The effects of concentration and number of sequential applications of PHD-Ca on shoot length of 'Granny Smith' apple trees in South Carolina (Expt.5, 1997).

\begin{tabular}{|c|c|c|c|c|c|c|c|}
\hline \multirow{2}{*}{$\begin{array}{l}\text { Treatment } \\
\text { no. }\end{array}$} & \multicolumn{5}{|c|}{$\begin{array}{c}\text { Concn applied at: } \\
{\text { (DAPF })^{z}}\end{array}$} & \multirow[b]{2}{*}{ Total } & \multirow{2}{*}{$\begin{array}{c}\text { Avg shoo } \\
\text { length } \\
(\mathrm{cm})\end{array}$} \\
\hline & 0 & 10 & 20 & 30 & 60 & & \\
\hline 1 & 0 & --- & --- & --- & --- & 0 & $119 a b^{y}$ \\
\hline 2 & 0 & --- & --- & --- & 125 & 125 & $120 \mathrm{a}$ \\
\hline 3 & 40 & 40 & 40 & 120 & --- & 240 & $108 \mathrm{a}-\mathrm{c}$ \\
\hline 4 & 40 & 40 & 40 & 120 & 125 & 365 & $96 b-d$ \\
\hline 5 & 40 & 40 & 40 & 40 & --- & 160 & $90 \mathrm{c}-\mathrm{e}$ \\
\hline 6 & 40 & 40 & 40 & 40 & 125 & 285 & $90 \mathrm{c}-\mathrm{e}$ \\
\hline 7 & 60 & 60 & 60 & 60 & --- & 240 & 70 ef \\
\hline 8 & 60 & 60 & 60 & 60 & 125 & 365 & $68 \mathrm{ef}$ \\
\hline 9 & 80 & 80 & 80 & 80 & --- & 320 & $60 \mathrm{f}$ \\
\hline 10 & 80 & 80 & 80 & 80 & 125 & 445 & $73 \mathrm{~d}-\mathrm{f}$ \\
\hline 11 & 100 & 100 & 100 & 100 & --- & 400 & $66 \mathrm{f}$ \\
\hline 12 & 100 & 100 & 100 & 100 & 125 & 525 & 74 ef \\
\hline
\end{tabular}

${ }^{2} \mathrm{DAPF}=$ days after petal fall

${ }^{y}$ Mean separation among all treatments by Duncan-Waller LSD, $P \leq 0.05$.

treatments 4, 5, and 6) were retreated in 1997, response did not differ from that of trees treated only in 1997 (data not shown).

Both four applications at $40 \mathrm{mg} \cdot \mathrm{L}^{-1}$ and three applications of 40 $\mathrm{mg} \cdot \mathrm{L}^{-1}$ plus one at $120 \mathrm{mg} \cdot \mathrm{L}^{-1}$ were less effective than four applica- tions of 60,80 , or $100 \mathrm{mg} \cdot \mathrm{L}^{-1}$ (Table 7). The three higher rates did not differ in their effects on shoot growth. Thus applying PHD-Ca in four equal applications was much more effective than applying low rates followed by a higher concentration. An additional application of 125 $\mathrm{mg} \cdot \mathrm{L}^{-1}$ at $60 \mathrm{DAPF}$ had no additional effect on growth.

Expt. 5. Shoot growth continued all summer in South Carolina, while in North Carolina growth had almost stopped by 8 July (Fig. 1). A sequence of four PHD-Ca applications at 10-d intervals beginning at PF was effective until early July at both locations. However, growth resumed in South Carolina, paralleling that of the control. The PHDCa treatment in North Carolina retarded growth until the control stopped growing in early July, but was unable to retard growth as effectively in South Carolina where control trees grew all summer.

Expt. 6. Application of $200 \mathrm{mg} \cdot \mathrm{L}^{-1}$ of PHD-Ca $21 \mathrm{DAPF}$ to vigorous, nonbearing 'Fuji' trees retarded shoot growth; the effect was similar to that of a combined Alar + ethephon spray (data not shown).

\section{DISCUSSION}

Under the climatic conditions of apple-producing areas of the southeastern United States, PHD-Ca has potential for effective, season-long control of vegetative growth in apple trees. However, timing seems to be very important. Multiple, low-rate applications are more effective than a single, high-rate treatment. A concentration of 50 to 60

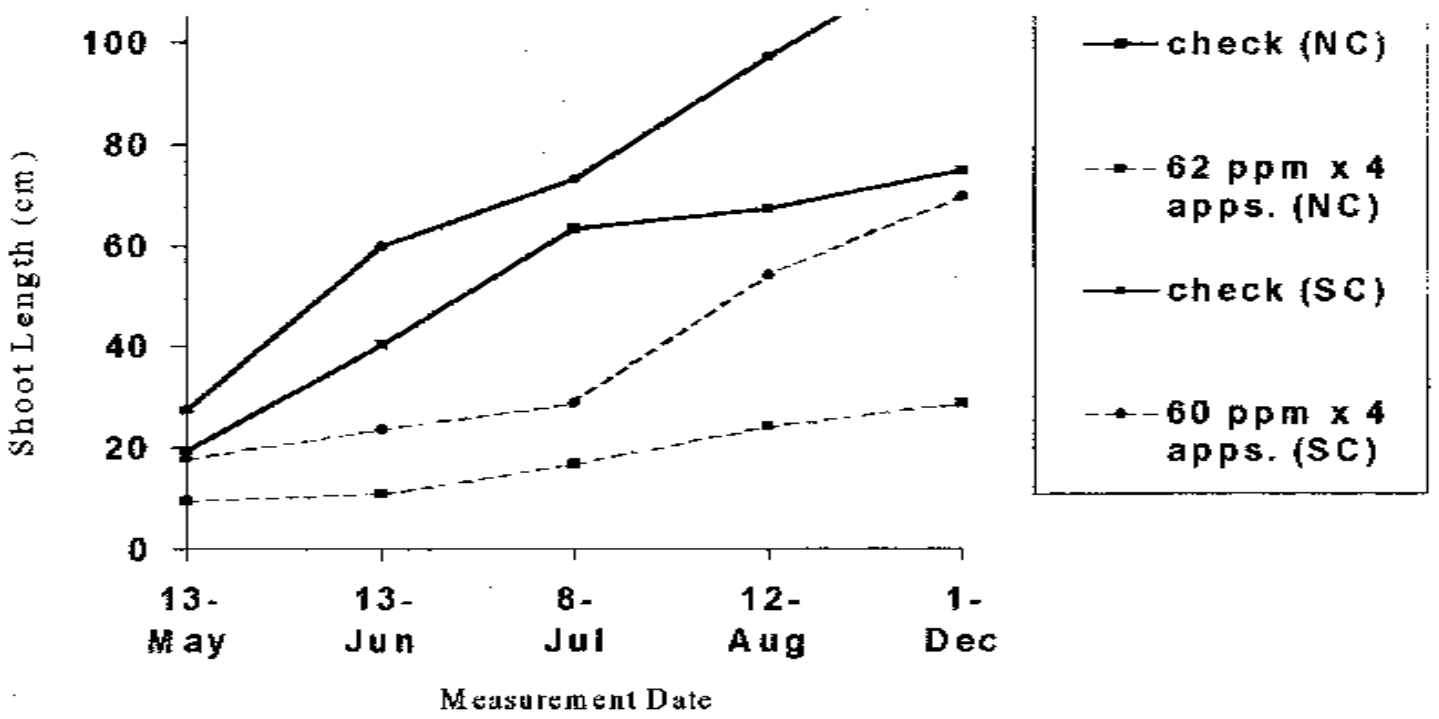

Fig. 1. Effects of PHD-Ca on shoot growth of 'Granny Smith' apple trees at a high (N.C.) vs. low (S.C.) elevation (Expt. 4 vs. 5, 1997).

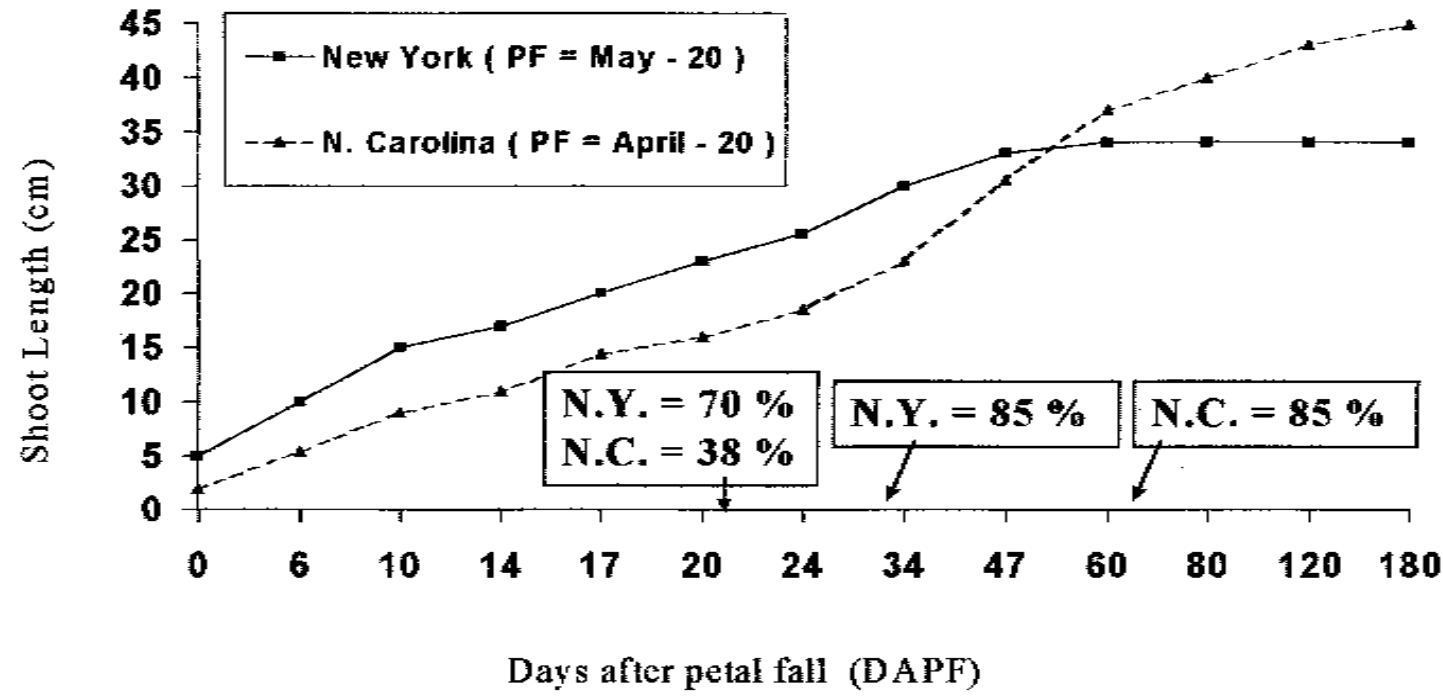

Fig. 2. A comparison of the seasonal shoot growth curve for 'Red Delicious' apple trees at Sodus, N.Y., vs. Hendersonville, N.C. (average of 2 years per location). 
$\mathrm{mg} \cdot \mathrm{L}^{-1}$ appears to be the lower limit for multiple applications. Initial findings suggest that if PHD-Ca application rates are kept at or below $125 \mathrm{mg} \cdot \mathrm{L}^{-1}$ during the sensitive fruit set period (PF to $14 \mathrm{DAPF}$ ), fruit quality is not altered (data not shown). Response to a single PHD-CA application appears to last 3-4 weeks, suggesting that multiple applications at 2-3-week intervals are appropriate.

A comparison of vegetative growth of 'Delicious' at Sodus, N.Y. (W.H. Palmer, personal communication), and Hendersonville, N.C., suggests that growth varies with latitude and related climatic conditions (Fig. 2). By 21 DAPF shoots in New York had achieved $70 \%$ of their final length, those in North Carolina only 38\%. New York trees took only $32 \mathrm{~d}$ to achieve $85 \%$ of total seasonal growth, but North Carolina trees required $65 \mathrm{~d}$. Thus timing and concentration, as well as need for multiple applications, will probably vary in different apple production areas.

If consistent tree size control can be obtained chemically, and this appears possible based on results presented, then reduced pesticide usage should result because of the smaller tree canopies. Additionally, reduced size and canopy density could improve light penetration into trees, and therefore improve fruit quality factors such as size and/or color. Location and climate, as well as cultivar response, will affect the timing and concentrations needed.

\section{Literature Cited}

Griggs, D.L., P. Hedden, K.E. Temple-Smith, and W. Rademacher. 1991. Inhibition of gibberellin $2 \beta$-hydroxylases by acylcyclohexanedione derivatives. Phytochemistry 30:2513-2517.

Greene, D.W. 1996. BAS-125 10W Controls growth and influences fruit quality of 'McIntosh' apples, p. 283-285. In: Proc. Plant Growth Regulat. Soc. Amer.

Nakayama, I., T. Miyazawa, M. Kobayashi, Y. Kamiya, H. Abe, and A. Sakurai. 1990. Effects of a new plant growth regulator, prohexadione calcium (BX-112), on shoot elongation caused by exogenously applied gibberellins in rice (Oryza sativa L.) seedlings. Plant Cell Physiol. 31:195200.

Nakayama, I., T. Miyazawa, M. Kobayashi, Y. Kamiya, H. Abe, and A. Sakurai. 1992. Effects of a plant growth regulator, prohexadione-calcium (BX-112), on the endogenous levels of gibberellins in rice. Plant Cell Physiol. 33:59-62.

Rademacher, W., K.E. Temple-Smith, D.L. Griggs, and P. Hedden . 1992. The mode of action of acylcyclohexanediones-A new type of growth retardant, p. 571-577. In: Progress in plant growth regulation. Kluwer Academic Publishers, The Netherlands.

Sutton, T.B. and C.R. Unrath. 1988. A comparison of handgun and tree-rowvolume pesticide applications. Plant Dis. 72:509-512. 